\title{
Latar Belakang Remaja Melakukan Bullying di Sekolah Menengah Kejuruan (SMK)
}

\author{
Dedeh Juwita Sari, Stefanus Adang Ides, Lina Dewi Anggraeini
}

Sekolah Tinggi Ilmu Kesehatan Sint Carolus Jakarta

JI. Salemba Raya No. 41, RT.3/RW.5, Paseban, Senen, Kota Jakarta Pusat, Daerah Khusus Ibukota Jakarta 10440, Indonesia Email: dedehjuwita181194@gmail.com

\begin{abstract}
Abstrak
Banyaknya kasus kekerasan yang terjadi pada anak usia sekolah saat ini sangat memprihatinkan bagi pendidikan maupun orang tua. Sekolah yang seharusnya menjadi tempat untuk menimba ilmu serta membantu membentuk kepribadian yang positif ternyata dijadikan tempat untuk pem-bullyan. Penelitian ini bertujuan untuk mengetahui latar belakang remaja melakukan bullying di Sekolah Menengah Kejuruan (SMK). Penelitian ini menggunakan metode kualitatif dengan desain fenomenologi yang dilaksanakan bulan Juli 2016 sampai dengan Mei 2017. Informan dalam penelitian ini adalah siswa SMK yang masih aktif bersekolah dan pernah melakukan bullying dengan teknik purposive sampling. Pengumpulan data dilakukan dengan wawancara mendalam (depth interview) dan alat pengumpulan data penelitian ini ialah peneliti sendiri yang dibantu dengan pedoman wawancara dan alat perekam handphone. Analisis data menggunakan teknik Colaizzi. Jumlah informan dalam penelitian ini 8 orang. Hasil analisis ditemukan 10 tema yaitu bullying, pola asuh demokratis, pola asuh otoriter, pola asuh permisif, pengaruh teman, ingin berkuasa, fanatisme perbedaan, sarana dan prasarana, respon guru, dan pengaruh media massa. Hasil penelitian ini menyimpulkan bahwa latar belakang remaja melakukan bullying dapat dipengaruhi oleh pola asuh keluarga, media massa, teman sebaya, dan iklim sekolah. Saran yang dapat diberikan kepada institusi pendidikan yaitu dapat menjelaskan kepada siswa-siswi di sekolahnya mengenai peraturan-peraturan yang telah dibuat oleh sekolah, agar tidak ada salah paham pada siswa dalam mempersepsikan tentang aturan sekolah yang berlaku.
\end{abstract}

Kata Kunci: bullying, remaja

\section{Teenager's Background Do Bullying In Vocational School}

\begin{abstract}
The number of casses of violance that occur in school age children today is very worrying for education and parents. This study aimed to determine teenager's background do bullying in vocational school (SMK). The school should be a place to gain knowledge and form a positive personality but currently used as place to do bullying. This study aimed to determine teenager's background do bullying in vocational school (SMK). This research uses qualitative method with phenomenology design which is implemented from July 2016 to May 2017. Informants in this study are vocational students who are still active in school and never do bullying with purposive sampling techniques. Data collection was done by interview and using instrument including interview guidelines, tape recorder handphone. Data analysis used is Colaizzi. The number of respondens in this study was 8 people. From the results of the analysis, there are 10 themes of bullying, democratic parenting, authoritarian parenting, permissive parenting, peer influence, wish to power, fanaticism of differences, facilities and infrastructure, teacher response, and mass media influence. The results of this study concluded that the background of teens bullying can be influenced by family parenting, mass media, peers, and school climate. The suggestion is the instituition educational that can explain about the rules at school and student can receive and understand why the rules should be made.
\end{abstract}

Keywords: bullying, peers group

Info Artikel:

Artikel dikirim pada 29 September 2017

Artikel direvisi pada 03 Oktober 2017

Artikel diterima pada 03 Oktober 2017

DOI: http://dx.doi.org/10.21927/jnki.2017.5(2).149-156 


\section{PENDAHULUAN}

Bullying adalah suatu perilaku agresif yang dilakukan oleh seseorang atau sekelompok remaja yang melibatkan ketidak seimbangan kekuatan dan dilakukan secara berulang-ulang dengan cara mencelakai melalui fisik ataupun psikis (1). Jenisjenis bullying dikelompokan menjadi 5 kategori yaitu kontak fisik langsung seperti memukul, mendorong, menggigit, menjambak, menendang. Kontak verbal langsung seperti mengancam, mempermalukan, merendahkan. Perilaku non-verbal langsung, melihat dengan sinis, menjulurkan lidah, menampilkan ekspresi muka yang merendahkan, mengejek. Perilaku non-verbal tidak langsung mendiamkan seseorang, memanipulasi persahabatan sehingga menjadi retak. Pelecehan seksual kadang dikategorikan perilaku agresi fisik atau verbal, meskipun anak laki-laki atau anak perempuan yang melakukan bullying cenderung sama-sama menggunakan bullying verbal namun pada umumnya perilaku bullying fisik lebih sering oleh anak laki-laki (2). Dalam sebuah penelitian menyatakan bahwa perilaku bullying yang lebih spesifik dan sering dilakukan adalah menyindir $(37,8 \%)$ dan melabrak (35,6\%) (3).

Perilaku bullying ini tidak langsung terjadi begitu saja terhadap remaja. Dalam sebuah penelitian menjelaskan bahwa alasan anak menjadi seorang perilaku bullying bisa disebabkan oleh beberapa faktor misalnya pola asuh keluarga, teman sebaya, iklim sekolah, dan media massa (4).

Pola asuh keluarga dijelaskan bahwa orangtua yang sering bertengkar atau sering berkelahi di depan anak mereka cenderung membentuk perilaku anak untuk menjadi lebih agresif (5). Hasil penelitian menyatakan bahwa dari 48 responden yang mengalami pola asuh yang paling tinggi adalah pola asuh otoriter dengan persentase 39,6\% (19 responden) sisanya adalah pola asuh permisif dan demokratis (6).

Kelompok teman sebaya yang memiliki masalah di sekolah akan memberikan dampak yang negatif bagi sekolah seperti perilaku kekerasan, membolos, rendahnya sikap menghormati, kepada sesama teman dan guru (7). Hasil penelitian menunjukkan bahwa peran kelompok teman sebaya berada pada kategori tinggi yaitu $35 \%$ dengan nilai $p(>0,05)(8)$.

Iklim sekolah meliputi lingkungan belajar, lingkungan fisik dan sosial, serta keamanan sekolah (4). Salah satu penelitian yang telah dilakukan menyatakan dalam penelitiannya ada hubungan antara iklim sekolah dengan perilaku bullying yang memiliki nilai $p(0,000)(9)$.

Dalam sebuah jurnal berpendapat bahwa pada usia 18 tahun, seorang anak telah menyaksikan 100.000 tindak kekerasan di televisi, umumnya menunjukkan tindak kekerasan (10). Dalam penelitiannya menunjukkan hasil adanya hubungan yang signifikan antara perilaku bullying dengan tayangan tindakan kekerasan di media massa $(p \leq 0,001)$.

Sekolah umum diAmerikatahun 2009 melaporkan $23 \%$ siswanya mengalami bullying setiap harinya (10). Komisi Perlindungan Anak Indonesia (KPAl) menyatakan kasus bullying menduduki peringkat teratas dalam pengaduan masyarakat. Di tahun 2011 sampai dengan Agustus 2014, KPAI mencatat 369 pengaduan terkait masalah tersebut dan diantaranya dalam bidang pendidikan terdapat 1.480 kasus bullying dalam bentuk kekerasan di sekolah. KPAI sudah membuat UU mengenai kasus bullying contoh UU No. 35 Tahun 2014 atas perubahan UU No. 23 tahun 2002 tentang Perlindungan Anak, pasal 9 ayat 1 secara tegas menyatakan (a), "setiap Anak berhak mendapatkan perlindungan di satuan pendidikan dari kejahatan seksual dan kekerasan yang dilakukan oleh pendidik, tenaga kependidikan, sesama peserta didik, dan/atau pihak lain (11).

Penelitian ini bertujuan untuk mengetahui latar belakang remaja melakukan bullying di Sekolah Menengah Kejuruan (SMK), karena ditemukan sebuah kejadian di salah satu sekolah yang dimana muridnya menjadi korban bullying sehingga membuat anak tersebut keluar dari sekolah.

\section{BAHAN DAN METODE}

Metode penelitian yang digunakan adalah metode kualitatif dengan menggunakan desain fenomenologi. Populasi yang digunakan dalam penelitian ini adalah siswa/siswi yang bersekolah di SMK. Jumlah informan dalam penelitian ini adalah 8 orang (sudah terjadi saturasi tema) yang berasal dari 4 sekolah SMK. Pengambilan sampel dilakukan dengan teknik purposive sampling.

Kriteria sampel yang telah ditetapkan oleh peneliti adalah informan yang pernah melakukan bullying dengan mewawancarai setiap guru BK yang ada di sekolah mengenai anak-anak yang pernah melakukan bullying, masih aktif di sekolah, dan bersedia untuk menjadi subjek penelitian. Alat penelitian yang digunakan adalah peneliti sendiri, alat perekam, serta pedoman wawancara. 


\section{HASIL DAN BAHASAN}

Penelitian ini menggunakan desain fenomenologi dengan analisis Colaizzi yang menghasilkan 10 (sepuluh) tema, yang merupakan jawaban dari 5 (lima) tujuan khusus peneliti, yaitu diketahui pemahaman remaja tentang bullying ditemukan 1 tema yaitu bullying, diketahui latar belakang pola asuh orang tua yang menyebabkan remaja melakukan bullying ditemukan 3 tema yaitu pola asuh demokratis, pola asuh otoriter, dan pola asuh permisif, diketahui latar belakang teman sebaya yang menyebabkan remaja melakukan bullying ditemukan 3 tema yaitu pengaruh teman, ingin menunjukan kekuasaan, dan fanatisme pada perbedaan, diketahui iklim sekolah yang menyebabkan remaja melakukan bullying ditemukan 2 tema yaitu sarana dan prasarana, dan respon guru, diketahui media massa yang menyebabkan remaja melakukan bullying ditemukan 1 tema yaitu pengaruh media massa berupa televisi.

Tema-tema yang di hasilkan dari penelitian ini selanjutnya akan dibahas secara terpisah untuk mengungkapkan latar belakang remaja melakukan bullying di sekolah. Tema-tema yang dihasilkan saling berkaitan satu sama lain untuk menjelaskan mengenai latar belakang remaja melakukan bullying.

\section{Pemahaman Remaja tentang Bullying}

Arti pemahaman adalah kemampuan seseorang untuk menangkap makna dan arti dari sebuah bacaan (12).

\section{Bullying (tema 1)}

Bullying adalah suatu perilaku agresif yang dilakukan secara berulang-ulang terhadap orang lain karena alasan tertentu. Dalam penelitian ini rata-rata mengartikan bullying sebagai perilaku merendahkan orang lain, menghina, melecehkan serta bercanda berlebihan.

Dari semua yang diwawancarai dalam memahami pengertian bullying mengarah ke jenis bullying yang pernah dilakukan oleh informan. Jenis bullying yang rata-rata dilakukan dari 8 informan adalah bullying non-fisik. 4 dari 8 informan menyatakan bahwa alasan mereka mem-bully adalah untuk keseruan, sisanya karena iseng dan alasannya teman yang duluan mem-bully. 7 dari 8 informan menyatakan bahwa mereka semua pernah merasakan di bully.

\section{Arti bullying}

Dari 8 informan mengartikan bullying hanya sebatas pada pemahaman bullying yang mereka tahu seperti mengejek (2 informan), merendahkan orang lain (2 informan), menghina (1 informan), dan bercanda berlebihan ( 1 informan).

\section{Bullying non-fisik}

Pemahaman tentang arti bullying, jenis bullying yang dilakukan oleh masing-masing informan adalah bullying non-fisik atau lebih sering adalah ngatangatain berikut adalah ungkapan 8 . Dalam sebuah penelitian perilaku bullying yang sering dilakukan oleh remaja adalah dengan melabrak $(35,6 \%)$ dan menyindir (37,8\%) (3). Jika dilihat dari hasil penelitian yang dilakukan ada kesesuain mengenai jenis bullying secara non-verbal yang dilakukan oleh informan.

\section{Alasan mem-bully}

Jawaban yang diungkapkan dari 8 informan bervariasi mengenai alasan mereka mem-bully orang lain. 4 orang informan mengatakan bahwa alasan mereka mem-bully adalah untuk keseruan, 2 orang hanya untuk keisengan, 1 orang menjawab karena temannya duluan yang memulai. Dari jawaban yang diungkapkan informan alasan melakukan bullying yang dilihat dari karakteristik informan cenderung kurang berempati terhadap teman-temannya. Remaja tidak memikirkan dampak dari bullying yang meskipun alasan remaja adalah hanya untuk keseruan atau keisengan saja.

\section{Korban bullying}

Semua jawaban informan yang didapat hampir rata-rata pernah menjadi korban bullying atau memiliki pengalaman masa lalu yang sama. Dari tema dan sub tema yang telah di dapatkan, muncul asumsi bahwa dari setiap informan yang memahami arti dari bullying merupakan cerminan dari jenis bullying yang dilakukan oleh informan. Selain itu dari pengalaman masa lalu yang dialami merupakan hal yang bisa memicu terjadinya pem-bullyian terhadap orang lain. Penelitian ini sejalan dengan penelitian terkait yang telah diungkapkan bahwa berdasarkan gambaran perilaku bullying pada subjek penelitian yang pernah menjadi korban maupun pelaku, ditemukan ada kesesuaian temuan perilaku bullying yang dilakukan dan dialami subjek penelitian yaitu bullying verbal dalam bentuk sindiran dan gosip (3). 


\section{Latar Belakang Pola Asuh Orang Tua yang} Menyebabkan Remaja Melakukan Bullying

Pengasuhan atau sering disebut pola asuh berarti bagaimana orang tua memperlakukan anak, mendidik, membimbing dan mendisiplinkan serta melindungi anak dalam mencapai proses kedewasaan, hingga kepada upaya pembentukan norma-norma yang diharapkan oleh masyarakat pada umumnya (13). Dalam penelitian ini ditemukan semua pola asuh yang biasanya diterapkan oleh orang tua pada umumnya yaitu pola asuh demokratis, pola asuh otoriter, dan pola asuh permisif. Berikut adalah skema mengenai pola asuh.

\section{Pola Asuh Demokratis (tema 2)}

Dari penelitian yang telah dilakukan 1 informan menyatakan bahwa orang tuanya di rumah jika ingin keluar rumah harus meminta ijin terlebih dahulu kepada orang tua. Dari pernyataan yang ada orang tua informan memberikan batasan sesuai dengan standar yang diberlakukan orang tua. Ini sesuai dengan sifat remaja yang tidak suka dikekang atau diberikan kebebasan yang berlebihan.

\section{Pola Asuh Otoriter (tema 3)}

Hasil penelitian yang didapat mengenai pola asuh otoriter ini didapatkan hasil wawancara dari informan bahwa 1 informan mendapatkan perlakuan untuk tidak diijinkan keluar rumah, 1 informan menyatakan bahwa dirumahnya ketat tidak boleh kemana-mana, 2 informan menjawab selalu dikekang. Pola asuh ini tampaknya membuat remaja tidak bisa mengeskpresikan dirinya. Orang tua tidak memberikan kebebasan sedikitpun kepada remja sehingga membuat mereka melakukan segala hal semau mereka sendiri. Pola asuh ini dirasa sangat tidak tepat untuk diterapkan diusia remaja karena usia remaja sedang mencari jati diri.

\section{Pola Asuh Permisif (tema 4)}

Kebebasan adalah hal yang paling diinginkan oleh remaja. Dimana masa remaja adalah masa yang dipenuhi dengan rasa penasaran serta ingin mencari jati dirinya sendiri. Seperti halnya pola asuh yang terlalu membebaskan anak dan melakukan kegiatan sesuka hati mereka tanpa adanya kendali dari orang tua adalah hal yang salah karena dapat memicu berbagai penyimpangan yang akan dilakukan oleh remaja tersebut. Dalam penelitian ini ditemukan 2 orang mengatakan mendapatkan kebebasan yang berlebihan, 1 orang mengatakan bahwa dirinya merasa tidak diperdulikan oleh keluarganya.

Pola asuh ini membuat anak semakin tidak memiliki arahan bahwa dirinya akan dibawa kemana tanpa adanya pengawasan dari orang tua. Pengasuhan orang tua yang terlalu membebaskan anak kemanapun anak pergi atau melakukan kegiatan apapun sesuka hati mereka pada akhirnya membuat mereka merasa bahwa orang tua tidak memperdulikan mereka. Pola asuh permisif merupakan pola asuh yang dapat menimbulkan perilaku bullying karena orangtua yang bersifat kurang mengontrol anak, membebaskan anak, anak kurang bimbingan dan membiarkan anak untuk melakukan apapun yang mereka inginkan (8). Hasil penelitian lain juga menunjukkan bahwa latar belakang para pelaku bullying memiliki kekhasan, sebagian dari mereka memiliki orang tua yang tidak memberikan bimbingan yang cukup mengenai perilaku positif, sehingga dengan pola asuh yang terlalu permisif, terlalu keras, atau tidak konsisten dalam menjalankan disiplin berpengaruh dalam pembentukan seorang anak memilik kecenderungan melakukan bullying terhadap anak lain (14).

Hasil penelitian yang didapatkan, bahwa kesalahan dalam menerapkan pola asuh dapat memberikan dampak yang negatif bagi remaja. Dikemukakan demikian karena pada masa remaja mengalami masa transisi atau peralihan dari masa anak-anak menuju masa kedewasaan yang sering ditandai dengan adanya krisis kepribadian. Pada dasarnya pola asuh demokratis tidak menjadikan faktor yang melatarbelakangi remaja melakukan perilaku bullying karena pola asuh demokratis merupakan pola asuh yang tepat dalam mengasuh remaja. Berbeda halnya dengan pola asuh otoriter dan permisif, pola asuh ini memberikan dampak yang kurang baik terhadap remaja karena tidak ada kebebasan terhadap anak untuk mencoba atau terlalu berlebihan dalam meberikan kebebasan.

Penelitian ini sejalan dengan penelitian yang telah di ungkapkan bahwa pola asuh ada hubungannya dengan perilaku bullying salah satunya adalah pola asuh otoriter dengan nilai $p 0,006(p \leq 0,005)(6)$.

\section{Latar Belakang Teman Sebaya yang Menyebabkan Remaja Melakukan Bullying}

Teman sepermainan memang dapat membawa dampak yang negatif untuk melakukan hal yang menyimpang. Salah satunya adalah perilaku bullying. Berikut adalah skema mengenai teman sebaya. 


\section{Pengaruh Teman (tema 5)}

Teman sebaya adalah teman yang memiliki persamaan usia, persamaan kelas ataupun jenjang pendidikan. Dari hasil penelitian mengenai pengaruh teman sebaya didapatkan 7 dari 8 informan menyatakan bahwa jika mereka sedang mem-bully teman, teman yang lain akan ikut tertawa dan 1 informan menyatakan ada yang memanas-manasi dirinya untuk terus mem-bully. Jika ada tekanan dari teman sebaya untuk melakukan bullying maka akan memberikan pengaruh besar pada setiap individu untuk melakukannya. Dengan bergaul bersama kelompok sebaya dan memahami hubungan yang erat dengan teman-teman tertentu.

\section{Ingin Berkuasa (tema 6)}

Bullying juga melibatkan kekuatan dan kekuasaan yang tidak seimbang, sehingga korbannya berada dalam keadaan tidak mampu mempertahankan diri secara efektif untuk melawan tindakan negatif yang diterima korban. Selain itu sering memerintah teman sebayanya layaknya orang yang memiliki kekuasaan besar. Dari hasil penelitian yang didapat 1 informan menyatakan bahwa dirinya didukung oleh teman sebayanya didalam geng yang dibentuk, sedangkan 1 informan menyatakan bahwa dirinya lebih sering menyuruh teman yang ada di gengnya. Jika dilihat dari karakteristik pelaku bullying pernyataan informan mengarah ingin menguasai teman-temannya. Kelompok teman sebaya yang mempunyai ikatan emosional yang kuat dan mereka dapat berinteraksi, bergaul, bertukar pikiran, dan pengalaman dalam memberikan perubahan dan pengembangan dalam kehidupan sosial dan pribadinya. Seperti halnya informan menyatakan bahwa temannya mendukung apapun yang dilakukan.

\section{Fanatisme pada Perbedaan (tema 7)}

Dari hasil penelitian yang didapatkan bahwa tingkah laku serta penampilan yang dirasa aneh dapat memicu terjadinya pem-bullyan. Seperti halnya yang diungkapkan oleh informan, 2 informan menyatakan dia melakukan bullying karena tingkah laku korban seperti wanita, 1 informan menyatakan tingkah laku korban yang aneh, dan 2 informan menyatakan korban berwajah lucu dan sebagai hiburan. Perbedaan yang ada baik fisik, agama, kemampuan ekonomi, hingga kemampuan akademik dipandang sebagai kelemahan yang tidak pantas untuk mendapatkan penghargaan.
Dari hasil penelitian yang didapatkan bahwa teman sebaya sangat mempengaruhi dalam melakukan bullying. Jika dikaitkan dengan fase remaja, remaja yang tergolong dalam penelitan ini adalah fase middle adolescent dimana pengaruh teman sebaya sangatlah besar di fase ini. Remaja tengah akan berusaha untuk mendapatkan teman baru agar memperbanyak teman diusianya. Bisa dilihat dari ungkapan-ungkapan informan dimana respon teman sebaya seperti tertawa mempengaruhi informan untuk terus melakukan bullying selain itu dari perilaku korban yang aneh pun kerap dijadikan sebagai bahan bullyian. Hasil penelitian ini sejalan dengan penelitian yang dilakukan menunjukkan peran teman sebaya memiliki kategori tinggi yaitu $35 \%$ dengan nilai $p(<0,05)(15)$.

\section{Latar Belakang Iklim Sekolah yang Menyebabkan Remaja Melakukan Perilaku Bullying}

Iklim sekolah merupakan salah satu penyebab terjadinya perilaku bullying di sekolah. Dari mulai sarana dan prasarana serta respon guru terhadap pelaku bullying ini dapat menimbulkan ketidak harmonisan di lingkungan sekolah. Berikut adalah skema mengenai iklim sekolah.

\section{Sarana dan Prasarana (tema 8)}

Sarana menurut KBBI adalah segala sesuatu yang dapat diapakai sebagai alat untuk mencapai maksud atau tujuan. Prasarana adalah segala sesuatu yang berhubungan dengan terselenggaranya suatu proses. Hasil penelitian ini menunjukan bahwa sarana dan prasarana sangat mempengaruhi remaja dalam perilaku bullying. 2 dari 8 informan menyatakan bahwa biasanya mereka melakukan bullying pada saat jam kosong atau saat guru sedang tidak ada didalam kelas. Selain itu peraturan yang ketat pun menjadi salah satu penyebab terjadinya bullying di sekolah.

Tingkat pengawasan di sekolah menentukan seberapa banyak dan seringnya terjadi peristiwa bullying (16). Pentingnya pengawasan dilakukan terutama di tempat bermain, ruang kelas, dan lapangan karena biasanya di ketiga tempat tersebut perilaku bullying kerap dilakukan. Apalagi keadaan di kelas sedang tidak ada guru yang mengajar seperti yang diungkapkan oleh informan.

Bullying juga terjadi jika pengawasan dan bimbingan etika dari para guru rendah, sekolah dengan kedisiplinan yang sangat kaku, bimbingan 
yang tidak layak, dan peraturan sekolah. Dari wawancara yang dilakukan oleh beberapa siswa mereka menjawab bahwa peraturan yang ketat justru membuat mereka semakin melanggar aturan yang ada di sekolah tersebut.

\section{Respon Guru (tema 9)}

Hasil penelitian yang telah dilakukan diperoleh bahwa respon guru yang meliputi sikap guru yang tidak tegas dan me-label anak yang melakukan bullying di sekolah akhirnya membuat anak semakin terus-menerus melakukan perilaku bullying tanpa diketahui oleh gurunya. Kurang tegasnya seorang guru ternyata dapat mempengaruhi kenakalan anak di sekolah, selain itu men-cap anak sebagai anak nakal merupakan perbutan yang tidak benar dan akhirnya anak tidak mau berubah. 2 informan menyatakan bahwa dirinya merasa guru-guru di sekolahnya kurang tegas, dan 2 informan menyatakan bahwa dirinya merasa di label anak nakal di sekolah.

Kecenderungan pihak sekolah yang sering mengabaikan keberadaan bullying menjadikan para siswa sebagai pelaku bullying mendapatkan penguatan terhadap perilaku tersebut untuk melakukan intimidasi pada siswa yang lain (15). Selain itu siswa yang sudah terkena label atau cap yang tidak baik di sekolahnya akan terus menerus di cap seperti itu. Sekolah yang di dalamnya terdapat perilaku diskriminatif berpotensi siswa untuk melakukan bullying di sekolah.

Dari hasil keseluruhan ditemukan bahwa iklim sekolah juga merupakan salah satu yang bisa dijadikan latar belakang mengapa remaja melakukan perilaku bullying di sekolah. Dari mulai sarana dan prasarana serta respon guru mempengaruhi bullying di sekolah. Penelitian ini sejalan dengan penelitian yang telah dilakukan bahwa terdapat pengaruh terhadap iklim sekolah dengan kecenderungan perilaku bullying pada siswa SMA kelas X Medan dengan didapat nilai $p(0,000)$ $<0,05$ diperoleh pula $r_{x y}=-0,323(9)$.

\section{Latar Belakang Media Massa yang Menyebabkan Remaja Melakukan Perilaku Bullying}

Dari penelitian yang dilakukan 6 informan yang menjawab bahwa media massa sangat berpengaruh terhadap dirinya untuk melakukan bullying. Berikut adalah skema mengenai media massa.

\section{Pengaruh Media Massa (tema 10)}

Media massa contohnya televisi merupakan media elektronik yang sangat mudah ditemukan di kehidupan sehari-hari. Tak heran jika media massa dapat menimbulkan dampak negatif seperti melakukan tindakkan bullying bagi yang melihatnya terutama remaja. Bullying sering dipertontonkan dan digambarkan sebagai perilaku lucu sehingga bullying dapat diterima sebagai hal yang wajar saja. Sebagai contohnya sering kali tayangan televisi (film, reality show, talk show), siaran radio, games, dimana didalamnya terdapat unsur-unsur kekerasan (memperlakukan seseorang, ejekan, menendang, memukul) yang dianggap sebagai suatu hiburan nantinya akan terakumulasi dalam pikiran anak yang dapat memicu anak untuk memlakukan bullying.

Media massa seperti televisi sangatlah cepat untuk dijadikan sumber informasi atau tontonan yang dapat menghibur masyarakat umum. Faktor media massa bisa menjadi penyebab terjadinya bullying seperti yang diungkapkan oleh Informan di atas. Penelitian yang telah dilakukan menyimpulkan bahwa tontonan melalui televisi atau film dapat menjadi bukti konkret untuk memicu terjadinya bullying baik dalam kurun waktu yang cepat ataupun lama (17). $\mathrm{Hal}$ ini menjadi alat paling ideologis yang dapat mempengaruhi karakter serta paradigma berfikir para siswa untuk meniru adegan-adegan yang ada dalam televisi tersebut. Penelitian terkait pun mengungkapkan hal yang sama mengenai media massa televisi, namun tidak hanya tontonan tindak kekerasan saja yang dijadikan penyebab bullying seperti yang diungkapkan oleh sebuah penelitian hasil dari penelitian ini menyatakan bahwa hasil analisis regresi berganda didapatkan indikator intensitas menonton tayangan kekerasan di televisi mempunyai mempunyai nilai thitung 9,226 dan nilai signifikan 0,000, nilai sig<0,05 menunjukkan bahwa terdapat pengaruh antara intensitas menonton tayangan kekerasan di televisi terhadap perilaku bullying (18).

\section{SIMPULAN DAN SARAN}

Penelitian ini mendapatkan hasil bahwa dari pengertian bullying yang diungkapkan informan merupakan perilaku bullying yang sering dilakukan informan kepada korban bullying. Selain itu dari pernyataan informan yang telah diungkapkan bahwa alasan informan melakukan bullying adalah hanya untuk keseruan dan tidak melihat dampak dari bullying itu sendiri.

Diharapkan institusi pendidikan dapat menjelaskan kepada siswa-siswi di sekolahnya 
mengenai peraturan-peraturan yang telah dibuat oleh sekolah, agar tidak ada salah paham pada siswa dalam mempersepsikan tentang aturan sekolah yang berlaku. Bagi tenaga kesehatan diharapkan mampu untuk mensosialisasikan mengenai bullying baik di lingkungan sekolah maupun di lingkungan masyarakat agar lebih mengetahui dampak dari bullying. Selain itu tenaga kesehatan khususnya bagian komunitas bisa membuat spanduk anti bullying dan dipasang disetiap lingkungan yang sudah diberikan sosialisasi mengenai bullying.

\section{RUJUKAN}

1. Vivolo A, Mathew R. What is Bullying? [Internet]. 2014 [cited 2016 Jul 14]. Available from: www. stopbullying.gov/blog

2. Riauskina II, Djuwita R, Soesetio SR. "Gencetgencetan" dimata siswa/siswi kelas 1 SMA: Naskah kognitif tentang arti, scenario, dan dampak "gencet-gencetan". J Psikol Sos [Internet]. 2005 Sep 1 [cited 2017 Sep 29];12(1). Available from: http://www.library.gunadarma.ac.id/journal/ view/4305/gencet-gencetan-di-mata-siswasiswi-kelas-i-sma-naskah-kognitif-tentang-artiskenario-dan-dampak-gencet-gencetan.html/

3. Tumon MB. Studi Deskriptif Perilaku Bullying pada Remaja [Internet]. 2014 [cited 2016 Jul 19]. Available from: www.journal.ubaya.ac.id

4. Hairani L. Pengaruh Persepsi Iklim Sekolah Terhadap Kecenderungan Bullying pada Siswa SMAX Medan. Institutional Repos Univ Sumatera Utara [Internet]. 2015 Sep 12 [cited 2017 Sep 29]; Available from: http://repository.usu.ac.id/handle/ 123456789/50266? mode=full

5. Yusuf H, Fahrudin A. Perilaku Bullying: Asessmen Multidimensi dan Intervensi Sosial. J Psikol Undip [Internet]. 2012 [cited 2017 Sep 29];11(2):1-10. Available from: http://download.portalgaruda.org/ article.php?article $=150840 \&$ val $=1286 \&$ title $=P E R$ ILAKU BULLYING: ASESMEN MULTIDIMENSI DAN INTERVENSI SOSIAL

6. Korua SF, Kanine E, Bidjuni H. Hubungan Pola Asuh Orangtua dengan Perilaku Bullying pada Remaja SMK Negeri 1 Manado. J KEPERAWATAN [Internet]. 2015 [cited 2017 Sep 29];3(2). Available from: https://ejournal.unsrat.ac.id/index.php/jkp/ article/view/7474

7. Benítez JL, Justicia F. Bullying: Description and Analysis of The Phenomenon. Bullying Descr
Anal phenomenon [Internet]. 2006 [cited 2017 Sep 29];4(42):1696-2095. Available from: http:// www.investigacion-psicopedagogica.org/revista/ articulos/9/english/Art_9_114.pdf

8. Usman I. Kepribadian, Komunikasi, Kelompok Teman Sebaya, Iklim Sekolah dan Perilaku Bullying. Humanitas (Monterey N L) [Internet]. 2013 [cited 2017 Sep 29];10(1):49-60. Available from: https://media.neliti.com/media/ publications/24533-ID-kepribadian-komunikasikelompok-teman-sebaya-iklim-sekolah-danperilaku-bullying.pdf

9. Palmer A, Davis, Hayes. Mass Media: What Has a Bigger Impact on Children's Bullying Behavior? [Internet]. 2014 [cited $2016 \mathrm{Jul}$ 28]. Available from: www.eaglefeather.honors.unt.edu

10. Sudaryono. Dasar-Dasar Evaluasi Pembelajaran. Yogyakarta: Graha Ilmu; 2012.

11. Susanto. 'Quo Vadis' Perlindungan Anak di Sekolah: Antara Norma dan Realita [Internet]. 2016. Available from: https://news.detik.com/ kolom/3122977/quo-vadis-perlindungan-anak-disekolah-antara-norma-dan-realita

12. Marwati W. Hubungan Pola Asuh Demokratis Orang tua dan Lingkungan Sekolah dengan Kecerdasan Emosional Anak Siswa SD Kelas V Kabupaten Sleman. 2014 [cited 2017 Sep 29]; Available from: http://eprints.uny.ac.id/13817/

13. Yuniartiningtyas F. Hubungan antara Pola Asuh Orangtua dan Tipe Kepribadian dengan Perilaku Bullying di Sekolah pada Siswa SMP. 2013 [cited 2017 Sep 29]; Available from: http://jurnal-online. um.ac.id/data/artikel/artikel59EF2430DFEFD3 1300B179B6C95C4F5A.pdf

14. Hidayati N. Bullying pada Anak: Analisis dan Alternatif Solusi. INSAN [Internet]. 2012 [cited 2017 Oct 2];14(1):41-8. Available from: http:// journal.unair.ac.id/filerPDF/artikel 5-14-1.pdf

15. Distefano C, Monrad DM, May RJ, Smith J, Gay J, Mindrila D, et al. Parent, Student, and Teacher Perceptions of School Climate: Investigations Across Organizational Levels. 2008 [cited 2017 Sep 29]; Available from: http://citeseerx.ist.psu. edu/viewdoc/download?doi=10.1.1.503.8201\&r ep=rep1\&type=pdf

16. Novianti I. Fenomena Kekerasan di Lingkungan Pendidikan. INSANIA [Internet]. 2008 [cited 2017 Sep 29];13(2):1-10. Available from: http://download. portalgaruda.org/article. php?article $=49325 \&$ val $=3912$ 
17. Levianti. Konformitas dan Bullying Pada Siswa. J Psikol [Internet]. 2008 [cited 2017 Sep 29];6(1). Available from: http://digilib.esaunggul.ac.id/ konformitas-dan-bullying-pada-siswa-4987.html

18. Suprihatin B. Hubungan Intensitas Menonton Tayangan Kekerasan di Televisi dan Intensitas
Pemberian Punishment dengan Perilaku Bulyying di Kalangan Pelajar SMA. J Educ Heal Community Psychol [Internet]. 2012 [cited 2017 Sep 29];1(1):76-86. Available from: http:// journal.uad.ac.id/index.php/Psychology/article/ view/3797 